\title{
CIFOR Research Abstracts
}

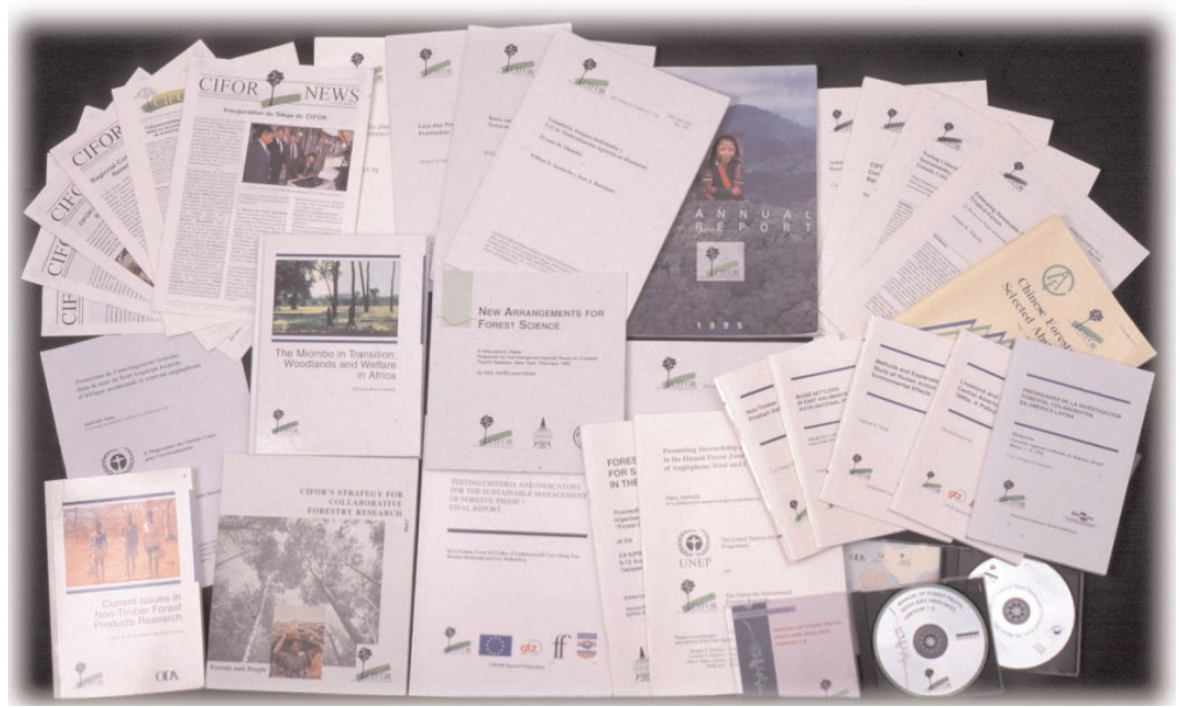



Center for International Forestry Research Bogor, Indonesia

November 1997 


\section{Contents}

Title Index. . . . . . . . . . . . . . . . .

Monographs $\ldots \ldots \ldots \ldots \ldots \ldots \ldots \ldots \ldots$

Occasional Papers $\ldots \ldots \ldots \ldots \ldots \ldots \ldots \ldots \ldots 4$

Special Publications. . . . . . . . . . . . . . . . . 14

CD-ROMs $\ldots \ldots \ldots \ldots \ldots \ldots \ldots \ldots \ldots \ldots 24$ 


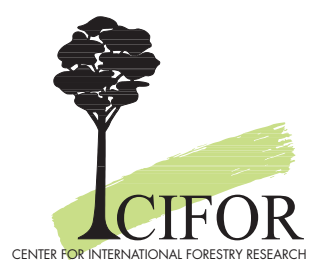

Mailing address: P.O. Box 6596 JKPWB, Jakarta 10065, Indonesia Office address: Jalan CIFOR, Situ Gede, Sindangbarang,

Bogor 16680, Indonesia

Tel: +62 (251) 622 622; Fax: +62 (251) 622100

E-mail: cifor@cgnet.com

WWW: http://www.cgiar.org/cifor 


\section{Title Index}

B

Bosques Secundarios como Recurso para el Desarrollo Rural y

la Conservación Ambiental en los Trópicos de América Latina.

Joyotee Smith, César Sabogal, Wil de Jong \& David Kaimowitz

Bugis Settlers in East Kalimantan's Kutai National Park.

Andrew P. Vayda \& Ahmad Sahur

C

Capacity for Forestry Research in the Southern African Development Community. G.S. Kowero \& M.J. Spilsbury

Cattle, Broadleaf Forests and the Agricultural Modernization Law of Honduras: The Case of Olancho. William D. Sunderlin \&

Juan A. Rodriguez

Current Issues in Non-Timber Forest Products Research.

M. Ruiz Pérez \& J.E.M. Arnold

Discussion Forum on Information Services in the Asia-Pacific and AGRIS/CARIS in the 21st Century - An Asia-Pacific Regional

Consultation. Edited by Michael Ibach \& Yvonne Byron 10

Diseases of Tropical Acacias. K.M. Old, Lee Su See \& J.K. Sharma

E

Environment, Development and Poverty: A Report of the International Workshop on India's Forest Management and Ecological Revival. Uma Lele, Kinsuk Mitra \& O.N. Kaul

F

Finding the Right Institutional and Legal Framework for CommunityBased Natural Forest Management: The Tanzanian Case. Liz Wily

Forest Operations for Sustainable Forestry in the Tropics.

Edited by Dennis P. Dykstra

Forestry Research within the Consultative Group on International

Agricultural Research. J.A. Sayer

G

Ganadería, Bosques Latifoliados y Ley de Modernización Agrícola en Honduras: El Caso de Olancho. William D. Sunderlin \& Juan A. Rodriguez 
Global Overview of Forest Conservation. Including: GIS digital files of forest and protected areas. Edited by Susan Iremonger, Corinna Ravilious \& Tim Quinton

$\mathrm{H}$

High Quality Planting Stock - Has Research Made a Difference?

Francis S.P. Ng

I

Initiatives on Assessing Sustainability: Status and Future Directions. Edited by Lay Cheng Tan

$\mathbf{L}$

Laju dan Penyebab Deforestasi di Indonesia: Penelaahan Kerancuan dan Penyelesaiannya. William D. Sunderlin \& Ida Aju Pradnja Resosudarmo

Livestock and Deforestation in Central America in the 1980s and 1990s:

A Policy Perspective. David Kaimowitz

M

Manual of Forest Fruits, Seeds and Seedlings on CD-ROM.

Francis S.P. Ng

Measuring and Monitoring Biodiversity in Tropical and Temperate Forests. Edited by Timothy J.B. Boyle \& Boonchoob Boontawee

Methods and Explanations in the Study of Human Actions and their Environmental Effects. Andrew P. Vayda

Miombo in Transition: Woodlands and Welfare in Africa.

Edited by Bruce Campbell

N

Non-Timber Forest Product Databases. Lay Cheng Tan, M. Ruiz Pérez \& Michael Ibach

$\mathbf{P}$

Prioridades de la Investigacion Forestal Colaborativa en America

Latina. César Sabogal

Production and Standards for Chemical Non-Wood Forest Products in China. Shen Zhaobang

Promoting Stewardship of Forests in the Humid Forest Zone of Anglophone West and Central Africa. Dennis P. Dykstra, Godwin S. Kowero, Albert Ofosu-Asiedu \& Philip Kio 
R

Rates and Causes of Deforestation in Indonesia: Towards a Resolution of the Ambiguities. William D. Sunderlin \& Ida Aju Pradnja Resosudarmo

$\mathrm{S}$

Saga of Participatory Forest Management in India. N.C. Saxena 22

Science and International Nature Conservation. J.A. Sayer 5

Social and Economic Aspects of Miombo Woodland Management in Southern Africa: Options and Opportunities for Research.

Peter A. Dewees

$\mathrm{T}$

Technologies for Sustainable Forest Management: Challenges for the 21st Century. J.A. Sayer, J.K. Vanclay \& N. Byron

Testing Criteria and Indicators for the Sustainable Management of

Forests: Phase 1 Final Report. Ravi Prabhu, Carol J.Pierce Colfer,

P. Venkateswarlu, Lay Cheng Tan, Rinekso Soekmadi \&

Eva Wollenberg

Tropical Moist Forests and Protected Areas: the digital files.

Edited by Jonathan Rhind and Susan Iremonger

W

Workshop on Barriers to the Application of Forestry Research Results.

C.T.S. Nair, T. Enters \& B. Payne 

Measuring and Monitoring Biodiversity in Tropical and Temperate Forests

Edited by Timothy J.B. Boyle \& Boonchoob Boontawee

Many estimates suggest that the world's forests are home to more than $50 \%$ of terrestrial biodiversity, yet temperate and tropical forests face numerous threats, including agricultural and industrial expansion, climate change, non-sustainable management and pollution. If forests and their diversity of living organisms are to be conserved, there is a need to measure and monitor biodiversity, in order that the impact of human activities and the efficacy of conservation measures can be assessed. As the concept of biodiversity covers the range of life itself, from genes to ecosystems, measurement and monitoring is extremely complicated.

This book contains 24 papers selected from among those presented at a IUFRO Symposium on the subject of "Measuring and Monitoring Biodiversity in Tropical and Temperate Forests", hosted by the Royal Forest Department of Thailand, at Chiang Mai, August 27th - September 2nd, 1994. The papers were selected to give as broad a coverage as possible of key topics, including Principles of Measuring and Monitoring Biodiversity (8 papers), Genetic Diversity (6 papers), Species and Ecosystem Diversity (5 papers), and Methodology (5 papers). Forest trees are the subjects of many papers, but also included are papers dealing with diversity of arthropods, microfungi, birds and butterflies, and gibbons, and others dealing with the entire range of biodiversity.

1995, 240pp., US\$10 (paper back - reprint)

ISBN 979-8764-01-3

\section{The Miombo in Transition: Woodlands and Welfare in Africa Edited by Bruce Campbell}

Miombo woodlands are the most extensive vegetation type in Africa south of the equator. These dry tropical woodlands cover some 2.5 million hectares and are home to over 40 million people. Miombo products are very important to the livelihoods and basic needs of an additional 15 million urban Africans.

The book demonstrates how much livelihood strategies of rural communities depend on miombo goods and services, and indicates the strong differentiation of uses within communities and in space and time. The ecological constraints to human activity in the region are clearly articulated, ranging from nutrient-poor soils to the presence of the tsetse fly. The authors also trace the host of policies that have influenced miombo wood- 
lands and their uses, from pre-colonial times to the present. The current importance of miombo products in markets, both locally and globally, is documented in a chapter on trade patterns. Options for management are outlined, including silvicultural treatment, fire management and grazing regimes. Institutional arrangements, both local and state, for the management of the woodlands are investigated, and the authors examine how local communities can be empowered to manage and benefit from the woodlands. The final chapter proposes a conceptual model of how all the diverse social, economic, political and ecological processes interact to shape how the household and woodland situations are changing. This conceptual framework is then used to identify key issues for research, which will reduce gaps in current understanding and facilitate formulation of new management strategies, policies and institutions.

The Miombo in Transition is a resource for researchers, with over 250 pages reviewing and synthesising over 400 studies. There are numerous figures, tables and plates. The book contains contributions by a number of researchers, and yet has managed to ensure coherence, close linking of chapters and complete coverage of material through authors' workshops and tight editorial control. Each chapter was reviewed by international experts both in draft and final format, resulting in the high quality of the final product.

1996, 266pp., US\$30

ISBN 979-8764-07-2

\section{Current Issues in Non-Timber Forest Products Research}

\section{Ruiz Pérez \& J.E.M. Arnold}

The book contains a number of commissioned background papers presented at the workshop on "Research on non-timber forest products" (Hot Springs, Zimbabwe, 28 August - 2 September 1995). Bringing together the experience from different regions and professional backgrounds, the book attempts to analyse the complexity of multiple use of forests from a multi-dimensional perspective that incorporates environmental, social, economic, technological, political, historical and cultural factors.

Current topics of discussion are reviewed. These include the possibility of matching the conservation and development agendas through promoting NTFP as proposed by a number of initiatives, the uni-directional path of development from extraction to intensive agricultural production, the roles of NTFP on people's livelihood strategies, the internal differentiation amongst communities, the different forms adopted by actions meant 
to secure tenure and their diverging effects, as well as the meaning and convenience of using NTFP as an analytical category.

A general conclusion to be drawn from the book is the need to build up an inter-disciplinary research agenda, as well as the need to employ more than one approach or method in addressing the complex situations that characterise the multiple use of forests.

1996, 264pp., US\$15

ISBN 979-8764-06-4 
Forestry Research within the Consultative Group on International Agricultural Research

J.A. Sayer

The early work of the research centres associated with the Consultative Group on International Agricultural Research (CGIAR) largely focused on increasing the productivity of food crops. Since the mid-1980s, the mandate of the CGIAR has been expanded to encompass forestry and agroforestry research. Research and related activities conducted in these two areas by CGIAR Centers is described with particular emphasis on detailing the activities of the Center for International Forestry Research (CIFOR), the newest member of the CGIAR.

Occasional Paper No. 1, 1994, 6pp.

\section{Social and Economic Aspects of Miombo Woodland Management in Southern Africa: Options and Opportunities for Research}

Peter A. Dewees

Five themes are identified for social, economic and policy research relating to miombo woodland management in southern Africa. They are: (1) patterns of local institutional change; (2) household use of woodland products; (3) markets for woodland products; (4) longer-term dimensions to woodland use and exploitation; and (5) policy and legislation. These themes are by no means definitive or exhaustive, but are described here as a means of focusing on the scope of future research, and as a basis for identifying priorities.

Occasional Paper No. 2, 1994, 28pp.

\section{Environment, Development and Poverty:}

A Report of the International Workshop on India's Forest Management and Ecological Revival

Uma Lele, Kinsuk Mitra \& O.N. Kaul

India is vast, diverse and complex, in its environments and in environmentsociety relations. These relationships, and government policies which influence or control them, are the subject of very significant reforms currently occurring in India. At the most fundamental level, this report asks "Who is to protect, manage and regenerate India's forests, where and for what, and what resources or support does each agent need to fulfill the mandate efficiently and equitably?" The conventional forestry systems 
have been under scrutiny. "Forestry" no longer means just industrial timber production by the Government, on government-owned lands. Other priority objectives (e.g. ecological and social sustainability) and other participants (farmers, communities, NGOs and industries) have emerged, and new modes of organisation are being explored and tested, such as Joint Forest Management. Is there a contradiction between "new goals and directions, such as JFM", but the old rules, structures and personnel? Is it possible to achieve the opposite goal with virtually the same apparatus as the 1950s? Or has it really been reformed? What further reforms and support (e.g. education, research, extension and investment funds) are required?

Occasional Paper No. 3, 1994, 32pp.

\section{Science and International Nature Conservation}

J.A. Sayer

International nature conservation programmes were originally driven by field biologists. As the environment has assumed increasing prominence on the international political agenda, the role of biologists has been marginalised. International programmes now have ambitious targets set by politicians and aspire to save the world. There is a need to balance these global environmental initiatives with a set of shorter-term practical actions to maximise biodiversity conservation. Biological scientists can co-operate with other natural resource specialists and social scientists in defining more targeted cost-effective nature conservation programmes. A case is made for the Prince Bernhard Chair at the University of Utrecht to focus on this interface between science and conservation practices.

Occasional Paper No. 4, 1995, 14pp.

\section{Report on the Workshop on Barriers to the Application of Forestry Research Results}

C.T.S. Nair, T. Enters \& B. Payne

Despite the increase in forestry research investment, the scientific base of forestry field practices remains weak, primarily due to the barriers to the application of research results. While barriers become visible at the application stage, their origin could be traced to all the preceding stages, including problem identification, research process and communication and extension. Mechanisms for identification of researchable problems, especially through the involvement of users are at best weak. The problem is 
further aggravated due to compartmentalised research, failure to incorporate local technical know-how and weaknesses in research management including inappropriate evaluation systems. A substantial proportion of research results are not communicated to potential users, but directed at other researchers. Even when relevant results are made available, they may remain unutilised as potential adopters may have objectives not taken into account while designing research. Also forestry services geared to enhance revenue in the short term may fail to take cognisance of the long-term benefits from the adoption of improved practices.

Occasional Paper No. 5, 1995, 33pp.

\section{Production and Standards for Chemical Non-Wood Forest Products in China}

Shen Zhaobang

Non-wood forest products are an important part of the forestry industry in China, particularly in poor mountain and forest areas. This paper concentrates on the present situation of chemical uses for non-wood forest products in China. It outlines the status of traditional products such as rosin, turpentine, tannin extracts and shellac, as well as pharmaceutical and health products. More recent developments in extraction and processing are also discussed. The prospects for chemical non-wood forest product extraction and utilisation are explored in the local and international contexts as contributors to the overall welfare of the Chinese population.

Occasional Paper No. 6, 1995, 18pp.

\section{Cattle, Broadleaf Forests and the Agricultural Modernization Law of Honduras: The Case of Olancho}

William D. Sunderlin \& Juan A. Rodriguez

The broadleaf forests of Honduras are among the most extensive in Central America and have been subject to rapid deforestation. Among the important factors in the process of deforestation has been the growth of cattle farming. Structural adjustment policies enacted in 1992 have been directed at overcoming grave economic problems. The authors of the adjustment plans have assumed the same policies will help protect the natural resource base of the country, including its forests.

Field research conducted in August - November 1994 sought to understand the effect of the 1992 Agricultural Modernization Law (AML) on the cattle sector and on the management of broadleaf forests in eastern 
Honduras. The research found that the cattle sector may have benefited from reforms introduced through the new policies (this remains to be proven), while state capabilities in forest conservation and management have clearly declined.

The recommendations of this report are to: (1) strengthen the capacity of the state to enforce existing laws aimed at protecting broadleaf forests; (2) revise and amend the provisions of the AML to include provisions aimed specifically at the protection of broadleaf forests; (3) strengthen efforts to harmonise policies among various economic sectors; (4) conduct a national cadastral survey and implement national land-use planning; and (5) strengthen official support and the policy environment for communitybased forest management.

There are three further research questions in need of attention: (1) Would intensification of the cattle sector assist efforts to reduce deforestation? (2) Is halting of road construction in the vicinity of forests a promising way of lowering rates of deforestation?; (3) To what extent is broadleaf deforestation alleviated through attention to the cattle sector alone?

Occasional Paper No. 7, 1996, 28pp.

\section{Ganadería, Bosques Latifoliados y Ley de Modernización Agrícola en Honduras: El Caso de Olancho} William D. Sunderlin \& Juan A. Rodriguez

Los bosques latifoliados de Honduras, entre los más extensos de Centroamérica, han sido objeto de una rápida deforestación. Uno de los principales factores en este proceso ha sido el desarrollo de la ganadería. Las políticas de ajuste estructural emitidas en 1992 han sido orientadas a resolver los graves problemas económicos del país. Los autores del plan de ajuste han supuesto que las mismas políticas ayudarían a proteger la base de los recursos naturales del país, incluyendo sus bosques.

Las investigaciones de campo realizadas entre agosto y noviembre de 1994 buscaron conocer los efectos de la nueva Ley de Modernización Agrícola (LMA) sobre la actividad ganadera y el manejo del bosque latifoliado en el oriente de Honduras. Se concluye que la actividad ganadera posiblemente se ha beneficiado de las nuevas políticas, lo cual aœn necesita comprobarse. También se desprende que la capacidad del estado para manejar y conservar el bosque ha disminuido.

Entre las recomendaciones del informe están: (1) fortalecer la capacidad del Estado para aplicar las leyes que ayudan a la protección del bosque latifoliado; (2) revisar las disposiciones de la Ley de Modernización Agrícola, incluyendo disposiciones que ayuden específi- 
camente al desarrollo del bosque latifoliado; (3) aunar esfuerzos para tratar de armonizar las políticas entre los diferentes sectores económicos; (4) actualizar el catastro nacional e implementar un plan nacional de uso de la tierra; y, (5) fortalecer el apoyo gubernamental al manejo forestal comunitario.

Quedan tres cuestiones pendientes: (1) ¿Podría la intensificación de la ganadería contribuir a disminuir la deforestación? (2) ¿Podría la paralización en la construcción de carreteras en las cercanías de las áreas boscosas, disminuir la tasa de deforestación? y (3) ¿En qué grado se reduciría la deforestación a través de la atención exclusiva al sector ganadero?

Occasional Paper No. 7 (Spanish), 1996, 30pp.

\section{High Quality Planting Stock - Has Research Made a Difference? Francis S.P. Ng}

Thirty years of research on planting stock in Malaysia, covering the period of a FAO/UNDP pine project, an enrichment planting effort with dipterocarps in natural forests, and a compensatory plantation project with fast-growing trees, had minimal effect on the course of events. The pine project and the enrichment planting project were both given up after about 15 years of effort and the compensatory plantation project is likely to end in the same way. The interface between research and application was more complicated than what managers and scientists were prepared for and the benefits of research were seldom realised.

Occasional Paper No. 8, 1996, 13pp.

Rates and Causes of Deforestation in Indonesia:
Towards a Resolution of the Ambiguities
William D. Sunderlin \& Ida Aju Pradnja Resosudarmo

There have been several major research efforts on the rate and causes of Indonesia's deforestation in recent years and much associated literature, but there is still no consensus in the research community on these issues. This paper reviews the areas of uncertainty and confusion, and proposes questions that must be answered to get a better grasp of the subject. Among the key questions are: (1) How are we to define "forest", "deforestation" and "agency" in the context of Indonesia? (2) What are the socio-economic characteristics and land-use practices of the various agents that have been lumped under the term "shifting cultivation"? (3) Is 
the relationship between increasing population density and loss of forest cover causal or incidental? (4) Why do some concessionaires appear to manage their sites relatively well, while many others do not? (5) What have been the net forest cover effects of macro-economic restructuring and changes of commodity prices since the early 1980s? Guidelines are proposed for improved research on the rate and causes of forest cover change. The paper closes noting the need to rise above a tendency to seek mono-causal explanations. Cogent explanations will necessarily be complex, since the causes reside in long-standing and broad socio-economic forces.

Occasional Paper No. 9, 1996, 19pp.

\section{Laju dan Penyebab Deforestasi di Indonesia: Penelaahan Kerancuan dan Penyelesaiannya William D. Sunderlin \& Ida Aju Pradnja Resosudarmo}

Sudah ada beberapa penelitian utama mengenai laju dan penyebab deforestasi di Indonesia akhir-akhir ini dan sudah banyak literatur yang berkaitan dengan hal tersebut, namun masih belum ada konsensus dalam dunia penelitian mengenai masalah-masalah ini. Makalah ini mengulas aspek-aspek ketidakpastian dan kerancuan yang ada, dan mengajukan pertanyaan-pertanyaan yang harus dijawab untuk mendapatkan pokok permasalahan. Diantara pertanyaan-pertanyaan pokok adalah: (1) Bagaimanakah kita mendefinisikan "hutan", "deforestasi" dan "pelaku deforestasi" dalam konteks Indonesia? (2) Apakah ciri-ciri sosio-ekonomis dan bagaimanakah praktek penggunaan lahan berbagai pelaku yang dikelompokkan begitu saja di bawah istilah "perladangan berpindah"? (3) Apakah hubungan antara naiknya kepadatan penduduk dan hilangnya tutupan hutan merupakan hubungan sebab akibat atau hanya kebetulan? (4) Mengapa beberapa pemegang konsesi nampaknya mengelola konsesinya dengan cukup baik, sedangkan banyak pemegang konsesi lainnya tidak? (5) Apakah pengaruh nyata restrukturisasi ekonomi makro dan perubahan harga-harga komoditas sejak awal 1980-an pada tutupan hutan? Diusulkan pedoman-pedoman untuk perbaikan penelitian mengenai laju dan penyebab perubahan tutupan hutan. Makalah ini diakhiri dengan catatan akan perlunya menghilangkan kecenderungan mencari penyebab tunggal. Penjelasan-penjelasan yang meyakinkan tentu saja tidak sederhana, karena penyebab-penyebab deforestasi tertanam dalam kekuatan-kekuatan sosio-ekonomis yang mapan dan luas jangkauannya.

Occasional Paper No. 9 (Indonesian), 1997, 22pp. 
Report on Discussion Forum on Information Services in the AsiaPacific and AGRIS/CARIS in the 21st Century - An Asia-Pacific Regional Consultation

Edited by Michael Ibach \& Yvonne Byron

The information available to researchers in today's world and the technology to access and utilise it is expanding rapidly. Unfortunately, most forestry and forestry research organisations in the Asia-Pacific region neither have access to nor can utilise effectively the vast amount of existing information for decision making.

A number of organisations in the region share common objectives to develop capacity in the forestry research sector. To this end, representatives of the ASEAN Forest Tree Seed Centre (AFTSC) Project, ASEAN Institute of Forest Management (AIFM), Center for International Forestry Research (CIFOR), International Development Research Council (IDRC) and $\mathrm{CAB}$ International (CABI), and the Forestry Research Support Programme for Asia and the Pacific (FORSPA) proposed solutions through collaborative activities.

This report is the proceedings of the Discussion Forum on Information Services in the Asia-Pacific held at Bogor, Indonesia, from October 30 to 1 November, 1996. The list of perceived needs generated by a preliminary survey guided the deliberations of the Forum. Participants identified priority goals, action plans for their achievement and responsible agents/ agencies, expected time frames and likely costs.

The Integrated Information System for the Agricultural Sciences and Technology (AGRIS) and the Current Agricultural Research Information System (CARIS) are part of the FAO's larger network providing an extensive, world-wide database of information on research in agriculture and related issues. To address the issue of AGRIS/CARIS in the 21st century, an Asia-Pacific Regional Consultation was held in conjunction with the Discussion Forum. This report documents the discussions designed to enhance co-operative activities and develop new approaches to improve the coverage of forestry literature in AGRIS and for forestry research information in CARIS among the countries in the Asia-Pacific region; as well as review new developments in information technology and their impacts on information providers and users.

A detailed, independent review was recommended to evaluate of AGRIS and CARIS, and their future directions in the 21st Century with special attention to the coverage of forestry information.

Occasional Paper No. 10, 1997, 106pp. 


\section{Capacity for Forestry Research in the Southern African Development Community \\ G.S. Kowero \& M.J. Spilsbury}

In 1995, a survey of research capacity was conducted at institutions undertaking forestry-related research in the Southern African Development Community (SADC) countries. This document presents a review of the methods available for the assessment of research capacity and summarises previous efforts to assess research capacity in the region.

The methodology adopted makes use of common indicators thereby allowing comparisons across institutions. The results of the survey are discussed and re-emphasise the need to prioritise manpower recruitment, training and development; only about half of the scientists researching forestry and related issues have sufficient training and scientific exposure. The management of research is another area requiring urgent attention in order to minimise the negative impacts of many of the economic and other externalities afflicting research in the region. About $17 \%$ and $28 \%$ of the institutions surveyed allocate more than $20 \%$ of their budgets and staff time respectively, to user groups. This raises questions on how research priorities are formulated and the relevance of the research in progress. There is considerable interaction between institutions in the region, but how this can translate into co-ordinated collaborative activities remains unclear.

The methodology for evaluating research capacity is also presented. Although the indicators for the various research capacity parameters do not capture the totality of capacity implications, they provide useful insights on the existing local capacity to undertake forestry research in eastern and southern Africa.

Occasional Paper No. 11, 1997, 45pp.

\section{Technologies for Sustainable Forest Management: Challenges for the 21st Century}

J.A. Sayer, J.K. Vanclay \& N. Byron

Technology will help to address the challenges for sustainable forestry in the 21 st century. Some of the challenges will include the shift of production from native forest to plantations in areas of comparative advantage, more efficient processing delinking end-use products from raw wood characteristics, increased demand, better information technologies to support decision makers, and more options for conserving biodiversity. Definitions of sustainability will vary in time and space as society's expectations and 
aspirations change, so there can be no "silver bullet" to ensure sustainability. However, progress may be facilitated with a systematic approach to forest management embracing the usual planning cycle: formulation of objectives, preparation of a strategy, planning, implementing, monitoring, and reappraisal. This requires a good understanding of each particular situation. Managers need good resource assessment and decision support systems; they must foster stakeholder participation in decisions, costs and benefits; and ensure effective procedures to resolve conflicts. Within an appropriate system, technical advances such as better machines and new implements may help to make a difference, but will not in themselves ensure sustainability. The important technologies for sustainable forestry are those that foster better communication between stakeholders and allow informed decisions spanning scales from the gene to the ecosystem. This remains an important challenge for forest managers in their search for sustainability.

Occasional Paper No. 12, 1997, 11pp.

\section{Bosques Secundarios como Recurso para el Desarrollo Rural y la Conservación Ambiental en los Trópicos de América Latina Joyotee Smith, César Sabogal, Wil de Jong \& David Kaimowitz}

Datos recientes muestran que la destrucción de los bosques primarios ha estado acompañada por la expansión de los bosques secundarios. Los estudios también muestran que los bosques secundarios son capaces de proporcionar algunos de los servicios económicos y ecológicos de los bosques primarios. Esto ha conducido a una nueva estrategia para aumentar el valor de los bosques secundarios para agricultores y ganaderos, con el objetivo de inducirlos a conservar estos bosques indefinidamente, o al menos a retardar su reconversión a otros usos. El objetivo de este artículo es de contribuir a una estrategia coherente para realizar el potencial de los bosques secundarios. Nuestra hipótesis es de que existen áreas importantes bajo bosque secundario en terrenos de pequeños y grandes productores y que a través de intervenciones tecnológicas y de política se puede incrementar significativamente el área y el valor económico y ecológico de bosques secundarios y, por consiguiente, el periodo por el cual estos son conservados. También formulamos la hipótesis de que los bosques secundarios son altamente variables en sus características ecológicas y en términos de objetivos y recursos de sus propietarios. Por tanto, es probable que las intervenciones requeridas sean altamente variables. Un análisis de la dinámica de los bosques secundarios puede ayudar a dirigir las intervenciones a aquellas áreas con la más alta probabilidad de impacto. El análisis de los 
aspectos socioeconómicos de la dinámica de bosques secundarios se basa en el cambio progresivo en el tiempo de algunas características de áreas de frontera agrícola. Hacemos la distinción entre dos trayectorias diferentes: aquella seguida por colonos y la de comunidades indígenas. Una tercera categoría de circunstancias accidentales, tales como conflictos militares y litigio, también pueden conducir a la creación de bosques secundarios.

Las opciones de manejo para bosques secundarios se clasifican de acuerdo a sus requerimientos de recursos (capital, tierra, mano de obra y capacidad gerencial) y el transcurso de tiempo para obtener un producto, resultando cuatro grupos: barbechos mejorados de ciclo corto, barbechos enriquecidos de ciclo medio, bosques de producción de ciclo medio a largo, y bosques de conservación. Las características de cada categoría de productores y sus bosques secundarios son contrastados con las características de las opciones de manejo donde la probabilidad de adopción es la más alta.

Luego se identifican las categorías generales de intervenciones de política apropiadas para cada categoría de productor, siendo: políticas relacionadas al mercadeo de productos del bosque secundario, reformas de la legislación y políticas que permiten a los productores capturar el valor de los servicios ambientales que suministran los bosques secundarios.

Concluimos enfatizando la importancia de un marco conceptual dinámico para el desarrollo de una estrategia para bosques secundarios, que permite prevenir la degradación del recurso, en oposición a revertir esta después de que ocurra. El marco conceptual que se presenta también permite el análisis de bosques secundarios como una parte integral del sistema de producción del agricultor. Finalmente, se enfatiza que la contribución principal de este ejercicio es el marco conceptual. Los resultados son meramente indicativos y necesitan ser verificados con datos empíricos. 
Methods and Explanations in the Study of Human Actions and their Environmental Effects

Andrew P. Vayda

Andrew P. Vayda, drawing on his long experience in studying the relations between people and their environments, addresses here the question of how human influences can be better incorporated into ecological studies. Citing relevant sources from the literature of philosophy as well as social and biological science, he argues that we should be guided in our research by the goal of giving causal explanations of concrete human behaviour and its concrete environmental effects. Existing theories and models may have a role in guiding such efforts, but developing or testing the theories and models need not be made the main objective.

Before illustrating his advocated approach with various studies (including his own research in Indonesian forests), Professor Vayda considers other approaches and indicates problems with them because of their failure to give due consideration to the chains of causally connected events leading to specific actions and their effects. Among the problematic approaches are those which assume that human behaviour affecting the environment is governed by basic conceptualisations or values concerning nature or the environment. Certain systems approaches to the study of environment-related human behaviour are also critically examined.

Special Publication, 1996, 44pp.

\section{Non-Timber Forest Product Databases}

Lay Cheng Tan, M. Ruiz Pérez \& Michael Ibach

A number of databases on non-timber forest products (NTFP) have been produced but any information available is mostly scattered and poorly advertised. It is necessary to survey the existence of such databases to provide information to interested and potential actors on what is available on NTFP, to co-ordinate future work and to avoid duplication.

The Center for International Forestry Research conducted a survey on NTFP databases principally to gather information and to assess such databases and their users. A workshop was held in December 1995 and this Working Paper incorporates results of the survey, brief reports of some of the databases and conclusions from the workshop.

Special Publication, 1996, 94pp.

ISBN 979-8764-02-1 
Initiatives on Assessing Sustainability: Status and Future Directions

Edited by Lay Cheng Tan

In a year marked by several formal expert-level meetings on certification of forest management and criteria and indicators for sustainable forest management (C\&I), most of which were related to the mandate of the Inter-governmental Panel on Forests (IPF), CIFOR and CATIE decided to lead off by hosting an informal meeting of experts from a cross-section of important certification and C\&I initiatives. Our desire was to facilitate an effective exchange of information between these initiatives, providing feedback to CIFOR, CATIE and other research institutions involved in the development of sustainability assessment methods and with a view to preparing the ground for subsequent IPF-related meetings in Kuala Lumpur, Brisbane, Bonn and Helsinki. The meeting was conducted under the umbrella of the International Project Advisory Panel (IPAP) of CIFOR's project on "Testing criteria and indicators for sustainable forest management".

This CIFOR/CATIE special publication is a report of the meeting. It contains an essay-type summary of the major points raised at the meeting and short summaries of twelve presentations made during panel discussions. The conclusions of this meeting will hopefully be an aid to other groups working on sustainability assessment and C\&I.

Special Publication, 1996, 52pp.

\section{Testing Criteria and Indicators for the Sustainable Management of Forests: Phase 1 Final Report \\ Ravi Prabhu, Carol J.Pierce Colfer, P. Venkateswarlu, Lay Cheng Tan, Rinekso Soekmadi \& Eva Wollenberg}

This is a report on the first phase of CIFOR's research project on testing criteria and indicators (C\&I) for the sustainable management of forests, which was initiated in August 1994. The project has sought to identify reliable, relevant and cost-effective C\&I based on field evaluation of existing sets under forest management unit (FMU) conditions in Germany, Indonesia, Côte d'Ivoire and Brazil. These evaluations were carried out using an inter-disciplinary and iterative approach developed by the project. This method is based on balancing the use of an inter-disciplinary team of experts and consultations with relevant stakeholders to evaluate C\&I within the frame-of-reference of a particular FMU. It has also been used successfully in an independent test carried out in Austria. 
Results from the field tests in Indonesia, Côte d'Ivoire and Brazil suggest that more than half of the C\&I related to policy and legal frameworks, ecological impacts, and production aspects were common to all three sites. There was however a marked and sharp decrease in this level of commonality when it came to C\&I related to the social aspects of forest management. Comparison of these results with those obtained from the test in Austria reveal that most of the C\&I identified as being common to the three tropical sites were also listed in the Austrian set. This suggests that at least in closed forest formations the development of a common "core" set of C\&I seems possible, however site-specific elements will continue to remain important particularly for social aspects and lower levels of hierarchy, such as verifiers.

In the second phase of the project, of two years duration, the aim is to develop a "toolbox" approach to sustainability assessment at the FMU level. This will include giving special attention to criteria and indicators identified as being weak during the first phase. Examples of such areas of weak C\&I are impacts on biodiversity and social sustainability. The research will continue to focus on improving C\&I especially with regard to their cost-effectiveness and reliability. In addition the project will test C\&I in forests managed by local communities, thereby adding variation to both the question of spatial scales and management objectives.

Special Publication, 1996, 217pp.

ISBN 979-8764-03- $X$

\section{Prioridades de la Investigacion Forestal Colaborativa en America Latina \\ César Sabogal}

Desde la fundación del CIFOR en 1993, las discusiones sobre cómo y en qué podría trabajar el Centro en América Latina han sido una constante dentro del proceso evolutivo que caracterizó los dos primeros años de la institución. En 1992 se realizó una consulta a nivel de América Latina y el Caribe sobre el papel del CIFOR en la investigación forestal. Desde la segunda mitad de 1994 y durante 1995, el CIFOR hizo esfuerzos pos llegar más frecuentemente a la región. Se realizaron una serie de viajes exploratorios, se diseñaron y prepararon varias propuestas de investigación con instituciones nacionales y regionales, se contribuyó con algunas iniciativas forestales a nivel subregional y en varias ocasiones se apoyó la participación de personas de la región en actividades de capacitación organizadas por el CIFOR. 
Como una forma de adelantar en este proceso, se consideró oportuno reunir algunas de las principales instituciones de investigación forestal de América Latina, con el fin de discutir el tipo de colaboración necesaria en las áreas de investigación estratégica más relevantes dentro del contexto socioeconómico y político de América Latina. Así, del 7 al 9 de marzo de 1996 se realizó en la ciudad de Manaus, Amazonía Brasileña, la Consulta

Regional sobre Prioridades de la Investigación Forestal Colaborativa, la cual tuvo como objectivos principales:

- Intercambiar ideas y buscar soluciones a algunos de los problemas asociados con la investigación forestal en la región y su impacto.

- Identificar áreas de prioridad para la investigación forestal colaborativa en la región y, entre estas, aquellas en las que el CIFOR podría colaborar efectivamente.

Se esperaba que dicho encuentro arrojara los siguientes resultados: (1) Una mejor visión, por parte de las instituciones participantes, de lo que es (y no es) el CIFOR, su agenda de investigación, cómo trabaja y qué clase de restricciones tiene; así como sobre las actividades que está actualmente realizando en América Latina. (2) Los insumos necesarios para que el CIFOR elabore un borrador de informe sobre las prioridades de la investigación forestal colaborativa en América Latina. (3) Un mecanismo para mejorar la comunicación y facilitar la colaboración entre las instituciones de investigación forestal en América latina.

El presente documento da cuenta de los principales resultados a que se llegó en este encuentro, incluyendo algunas de las presentaciones realizadas y parte del material que sirvió como insumo para la Consulta.

Special Publication, 1996, 116pp.

ISBN 979-8764-05-6

\section{Livestock and Deforestation in Central America in the 1980s and 1990s: A Policy Perspective}

\section{David Kaimowitz}

This study analyses seven factors used to explain the conversion of forest to pasture in Central America between 1979 and 1994: 1) favourable markets for livestock products; 2) subsidised credit and road construction; 3) land-tenure policies; 4) limited technological change in livestock production; 5) policies which reduce timber values; 6) reduced levels of political violence; and 7) characteristics specific to cattle which make conversion attractive. 
Deforestation rates in Central America declined in the 1980s, but remained high. After expanding rapidly, cattle population and pasture area have stagnated, although they continue to expand on the humid tropical frontier. Strong markets for beef and dairy products stimulated livestock expansion and deforestation in the 1960s and 1970s after which markets for livestock products became less favourable, which led to lower investment.

During the 1960s and 1970s large government subsidies for cattle raising encouraged forest conversion. Since then credit subsidies have been reduced, but subsidised public road construction continues, causing widespread deforestation. Land speculation is another reason why pasture expansion has continued in agricultural frontier areas.

There is little evidence that technological progress in livestock production reduces deforestation. Nor is it clear that removing policies which discriminate against forest production would have a major positive effect in this regard.

The author proposes: 1) restrictions on road construction and livestock credit in agricultural frontier areas; 2) increased enforcement of land-use restrictions in protected areas; 3 ) the expansion of land rights for indigenous peoples; 4) stronger restrictions on the titling of natural lands by large landholders; 5) pilot efforts to establish local land taxes with higher rates for pasture and crop lands than for forest; and 6) economic incentives for secondary forest regeneration and research on pasture degradation in Central America.

Special Publication, 1996, 88pp.

ISBN 979-8764-08-0

\section{Bugis Settlers in East Kalimantan's Kutai National Park Andrew P. Vayda \& Ahmad Sahur}

What policies should be adopted regarding enclave populations in national parks and other protected areas and how should the policies be implemented? These questions are important for protected areas throughout the world. Andrew P. Vayda and Ahmad Sahur report here on socio-economic and historical research that they conducted in the rapidly industrialising Indonesian province of East Kalimantan to help deal with such questions. They use their findings to make practical recommendations about relocating Bugis farmers and fishers from East Kalimantan's Kutai National Park and to assess relocation as an alternative to maintaining the status quo with respect to settlements within the Park's lowland rainforest. In addition, their findings are used to challenge some widely held generalisations about 
the impoverished condition of forest settlers, the preferability of land to only cash to those who might be resettled, and the inter-relations between urban/industrial employment and forest destruction.

The report is methodologically interesting as well. It shows how data collection and analysis may be guided by the goal of obtaining causal histories of events (including such events as forest-clearing in particular places at particular times and past changes in work and residence by settlers in the National Park). It shows how data collection and analysis, thus guided, may lead to significant research findings not obtained by investigators using rapid appraisal and standard survey methods and pre-set questionnaires. Also featured in the report are some methodological reflections on the value and limitations of applying general knowledge and cultural information, and on the need for information about particular historical events, in studies like Vayda and Sahur's.

In their research in and around Kutai National Park in 1996, Vayda and Sahur were resuming a collaboration begun in East Kalimantan sixteen years earlier. Andrew P. Vayda is Professor of Anthropology and Ecology at Rutgers University in New Brunswick, New Jersey, USA, and was, at the time of the research reported here, a Distinguished Visiting Scholar at CIFOR. Ahmad Sahur lectures in anthropology at Hasanuddin University, Ujung Pandang, South Sulawesi, Indonesia, and serves there also as an assistant dean.

Special Publication, 1996, 54pp.

ISBN 979-8764-12-9

\section{Promoting Stewardship of Forests in the Humid Forest Zone of Anglophone West and Central Africa}

Dennis P. Dykstra, Godwin S. Kowero, Albert Ofosu-Asiedu \& Philip Kio

A UNEP-sponsored project, implemented by CIFOR focused on the West African humid forests of Ghana and Nigeria. Liberia, Sierra Leone and Cameroon also were included in the study. The general objective of the project was to integrate all available information on humid forest formations in this region in order to promote initiatives to foster the adoption of sustainable forest management principles.

The report is organised into nine chapters. The first chapter gives an account of the forestry situation in West and Central Africa, with emphasis on vegetation distribution and factors affecting forest management. Chapters 2 and 3 highlight past and present silvicultural and forest management practices and also consider management control systems. The relevance of biodiversity and the role of non-timber forest products are 
explored in Chapter 4. Inter-generational issues, socio-economic factors influencing sustainable forest management, and the relevance of policies and legislation are addressed in Chapters 5, 6 and 7. Chapter 8 outlines strategies and incentives which might be adopted to promote sustainable forest management. The report concludes with suggestions for research which could be undertaken to fill gaps in knowledge which became apparent in the course of this project.

The project contributes to a larger joint project currently being undertaken by CIFOR and the Government of France for the Francophone countries of Côte d'Ivoire, Cameroon, Central African Republic, Congo and Gabon.

The report is available in English and French.

Special Publication, 1996, 103pp. ISBN 979-8764-09-9 (English)

ISBN 979-8764-14-5 (French)

\section{Forest Operations for Sustainable Forestry in the Tropics}

Edited by Dennis P. Dykstra

Forest harvesting and transportation operations are essential components of sustainable forestry. Recognition of these important factors was consistent with the theme of the XX IUFRO World Congress, "Caring for the Forest: Research in a Changing World". The Congress was held in Tampere, Finland, in August 1995. As part of the proceedings a forum was provided for discussion of new techniques for planning, implementing and controlling forest operations in ways that promote sustainable management of tropical forests.

This volume is the Proceedings of the Symposium organised by IUFRO Subject Group S3.05-00, "Forest Operations in the Tropics". A range of technologies is discussed across a number of regions. A paper by Migunga discusses forest soil compaction in Tanzania, while Cordero and Howard evaluate the use of oxen for logging operations in Costa Rica. Rubini Atmawidjaja addresses the management of ecosystems in Indonesia to balance human and environmental needs. Elias studies forest harvesting damages in East Kalimantan while Aulerich reviews the application of skyline systems by one Indonesian company. Shi Mingzhang presents the forest management accomplishments of the Leizhou Forestry Bureau in Quandong province, southern China. A Mexican case study of damage evaluation in a timber yarding operation is presented by Hernández-Diáz and Delgado-Pacheco while the situation for forest operations in the Amazon Basin is reviewed by Malinovski. Cedergren et al. 
assess the impacts of selective logging on silvicultural values in a mixed dipterocarp forest of Sabah.

Special Publication, 1996, 60pp.

ISBN 979-8764-10-2

\section{Diseases of Tropical Acacias}

K.M. Old, Lee Su See \& J.K. Sharma

Acacias are of considerable social and industrial importance for tropical reforestation and it is expected that about 2 million hectares will be established in South-east Asia by the year 2000. The acacia species currently of most interest for plantation forestry in the tropics are indigenous to northern Australia, Papua New Guinea and Irian Jaya.

Recent reports from Malaysia, Indonesia, Thailand and northern Australia suggest that the future productivity of acacia plantations may be affected by fungal pathogens including leaf spots, shoot blights, stem cankers, heart rot, root rots and gall rusts. During 1995-96 a series of disease surveys was undertaken by forest pathologists in native stands, trials, and operational and social forestry plantings of tropical acacias in Australia, India, Indonesia, Malaysia and Thailand to assess the potential of fungal pathogens as limiting factors to tree growth and productivity and to assess the relative importance of individual fungal pathogens. Tree species included in the surveys were Acacia mangium and A. auriculiformis, on the basis of their current importance as plantation species. A. crassicarpa and $A$. aulacocarpa were also surveyed as, although they have been planted on a limited scale so far, they are included in provenance and species trials in many locations throughout the region. Scientists who had participated in the project met with research managers of five major Indonesian plantation pulp and paper companies and government business enterprises April 28 - May 31996 at the base camp of PT Musi Hutan Persada Subanjeriji in southern Sumatra, to present the results of their surveys. This publication is a status report on the diseases of acacias in the several countries based on information presented at the workshop. It provides a benchmark of the current knowledge of the pathology of the four most important Acacia species currently being grown in plantations in tropical areas of South-east Asia, the Indian sub-continent and northern Australia.

The surveys and workshop were made possible through funding from the Australian Centre for Agricultural Research (ACIAR), the Center for International Forestry Research (CIFOR) and the support of the organisations of the participating scientists. 
The Saga of Participatory Forest Management in India N.C. Saxena

After about a hundred years of exclusive government control, forests in India are now being increasingly managed with people's participation. Almost all states in India have passed enabling resolutions to facilitate what is now popularly called the Joint Forest Management (JFM) programme. However, its implementation has so far been uneven. Field officers are often loath to share power and authority with the people, while expecting them to protect forests without wages. It is also not very well known under what conditions JFM does well, and whether these conditions are internal or more influenced by governmental policies.

Based on the author's repeated visits to JFM villages in several Indian states, this book provides a critique of the past and current forest policies, reviews the implementation of participatory forest management in five Indian states, explains why communal action is sustained over time, and places its conclusions in the wider theory of property regimes.

The book attempts a synthesis of diverse experience in participation, and links hypotheses of collective action with empirical evidence. One of the first source books on Joint Forest Management, it will be of value to donor agencies, state governments, policy makers and researchers on participatory development programmes.

Special Publication, 1997, 214pp.

ISBN 979-8674-15-3

\section{Finding the Right Institutional and Legal Framework for Community-Based Natural Forest Management: The Tanzanian Case Liz Wily}

As community involvement in natural forest management expands and matures, the need to lodge the rights and obligations of both state and community in workable and legally binding institutional frameworks becomes more pressing. This is particularly so where power and authority are being redistributed.

This paper looks specifically at Tanzania, where forest-local communities are beginning to be designated as the management authority of particular woodlands and, in some cases, even their owners. Positive results are giving considerable support to community-based management as the forest management strategy of choice. Implementation has of necessity 
also prompted a search for accessible mechanisms through which community authority may be embedded legally.

The author argues that, in this respect, Tanzania has an advantage over many sub-Saharan African states in the unusual manner of legal identity granted to rural communities, and in supporting administrative and land laws which provide for village-based control over natural resource management. Specific elements explored include the fact that rural villages in Tanzania are recognised as a formal level of government, endowed thereby with certain rights and obligations; that the rural village may attain legal corporate status, allowing it, inter alia, to own and manage property in ways accountable in a court of law; and that property law provides for a modern, statutory version of communal tenure, within the bounds and accountability of a private legal person.

The author provides a step by step guide to the ways in which a forestadjacent community may secure custodianship over a local natural forest, whether it be an already gazetted Forest Reserve or public land forest, and be held accountable for sound conservationary management.

Special Publication, 1997, 57pp. ISBN 979-8764-16-1 
Manual of Forest Fruits, Seeds and Seedlings on CD-ROM

Francis S.P. $\mathrm{Ng}$

The Manual of Forest Fruits, Seeds and Seedlings on CD-ROM provides descriptions of 310 genera, supported by 390 drawings, 470 black-andwhite and 310 colour photographs. It is conceived primarily as a guide for the identification of living seedlings in Peninsular Malaysia. However, most of the genera described here occur throughout South-east Asia and many extend to India and the South Pacific. Information is easily accessible through menus structured according to family names, genus names or Malay names. Additional main features include free text search of the entire database contents and a botanical identification key. This CD-ROM was produced by CIFOR as a pilot project to build capacity in application of multimedia technology.

The first edition of the manual was produced in two volumes: volume 1 was published in 1991 and volume 2 in 1992.

CIFOR CD-ROM Publication No. 1, 1996, US\$15

Version 1.0

Tropical Moist Forests and Protected Areas: the digital files Edited by Jonathan Rhind and Susan Iremonger

The World Conservation Monitoring Centre (WCMC) and the Center for International Forestry Research (CIFOR) are distributing spatial data on the world's tropical moist forests and protected areas on CD-ROM. The forest information was compiled from a multitude of national and international sources, including the TREES project of the European Commission. The many different forest classifications have been harmonised by WCMC to produce the first global overview of lowland and montane forest types.

WCMC/CIFOR CD-ROM Publication, 1996, US\$150

Version 1

\section{A Global Overview of Forest Conservation}

Including: GIS digital files of forest and protected areas

Edited by Susan Iremonger, Corinna Ravilious \& Tim Quinton

The CD-ROM is the second in a series of CD products designed mainly for the distribution of global forest GIS files. This new CD presents for the first time the forest cover of the whole world at a resolution of about $1 \mathrm{~km}^{2}$, 
in 26 different forest categories, both tropical and non-tropical. Also on the CD are WCMC's Protected Areas spatial data files, which present all the protected areas in each country in IUCN categories I-IV. Additionally there are spatial data sets for ecological zones around the globe. All of these GIS files can be used even if you do not have a GIS program, by downloading the free viewing package from the World Wide Web site of ESRI.

The CD-ROM also contains a statistical analysis that was performed using the forest, protected areas and ecological zones data that are on the CD. The analysis shows how much forest of each type is in each country of the world, and groups these into regions for a better general overview picture. It also documents how much of the forest is protected in each country, and also gives this information by ecological zone. The regions of the world are finally all grouped together to give a truly global overview of the amount of forest in the world, the amount protected, and the forest types that are of very limited distribution and without any protection. These should be the focus of evaluation for conservation efforts.

Preliminary analyses with population data show that the world has 0.7 ha of forest for each person, but if the rates of forest change published by FAO for each region for the period 1980-1990 continue, and UN population growth models are correct, this will be only 4.6 ha by the year 2025 .

All of the regional maps of forests, protected areas and ecological zones are immediately viewable as picture files on the $\mathrm{CD}$.

WCMC/CIFOR CD-ROM Publication, 1997, US\$ 250

Version 2 
To order CIFOR publications, please contact:

Communications Unit

CIFOR

P.O. Box 6596 JKPWB

Jakarta 10065

Indonesia

Tel: +62 (251) 622622

Fax: +62 (251) 622100

E-mail: cifor@cgnet.com

For ordering priced publications, please send your credit card details (cardholder's name, credit card number, expiry date and signature) to us. We accept only Visa/Master Card. 


\section{CIFOR}

\section{Research Abstracts}

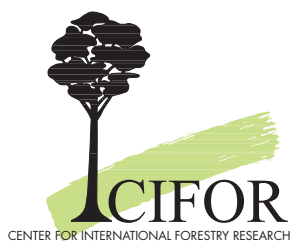

